\title{
ОСОБЛИВОСТІ ПАТОМОРФОЛОГІЧНИХ ЗМІН СПОЛУЧНОЇ ТКАНИНИ У ХВОРИХ $З$ НЕСПРОМОЖНІСТЮ ШВІВ ПОРОЖНИСТИХ ОРГАНІВ ТРАВЛЕННЯ
}

\section{Войтів Я. Ю.}

\section{ВСТУП}

Неспроможність швів анастомозів порожнистих органів травлення $\epsilon$ одним із найважчих ускладнень в абдомінальній хірургії. Частота виникнення таких ускладнень, за даними різних авторів, сягає від 2-8,1\% за тонкокишкових анастомозів до 3,8-14,6\% - за операцій на товстій кишці ${ }^{1}$. Розвиток неспроможності анастомозів супроводжується летальністю $14-21,7 \%^{2}$, у разі розвитку розповсюдженого перитоніту, абдомінального сепсису летальність виростає до 43$82,9 \%^{3}$. До цього часу в хірургічній спільноті немає єдиної точки зору на причини розвитку неспроможності швів, алгоритму хірургічної тактики в разі розвитку цих ускладнень.

Згідно 3 літературними даними серед факторів ризику розвитку неспроможності швів $€$ порушення мікроциркуляції в ділянці анастомозу, порушення регенерації тканини, інфекція, підвищення внутрішньокишкового тиску, зміни реологічних властивостей крові, грубі порушення гомеостазу тощо ${ }^{4}$. Окремою групою факторів ризику $\epsilon$ тактичні та технічні помилки під час формування анастомозів. До тактичних помилок можна віднести формування анастомозів в умовах поширеного гнійного перитоніту, кишкової непрохідності, порушень мезентеріального кровообігу, за декомпенсованої супутньої патології, а також необгрунтовану відмову від методів захисту анастомозу. Технічними помилками слід вважати порушення під час

1 Boyko V.V., Leonov A.V., Taraban I.A., Lehachov V.K., Leonov V.V. Nespromozhnist kyshkovykh anastomoziv. Kharkivska khirurhichna shkola. 2013; 6(63):5-8. [In Ukrainian].

${ }^{2}$ Pitel S., Lefèvre J.H., Tiret E. Redo coloanal anastomosis: a retrospective study of 66 patients. Ann Surg. 2012; 256 (5):806-811.

${ }^{3}$ Sharonne de Z., Usama A.A., Rogier A.R. Update of complications and functional outcome of the ileo-pouch anal anastomosis: overview of evidence and meta-analysis of 96 observational studies. Int. J. Colorectal Dis. 2012; 27:843-853.

${ }^{4}$ Manu L.N., Malbrain G. Incidence and prognosis of intraabdominal hypertension in mixed population of critically ill patients: A multiplecenter epidemiological study. Crit Care Med. 2005; 33:315-322. 
мобілізації, натяг у ділянці анастомозу, відсутність прецизійної адаптації країв рани, помилки у виборі шовного матеріалу, порушення принципів використання сучасних зшивальних апаратів.

Незважаючи на те, що роль регенераційних процесів у формуванні міжкишкових анастомозів $\epsilon$ безсумнівною ${ }^{5}$, наукових публікацій та досліджень на сучасному методичному рівні на цю тему недостатньо. Необхідне поглиблене вивчення механізмів репаративної регенерації в ділянці анастомозу та можливостей стимуляції регенераційних процесів, адекватного відновлення морфофункціональних характеристик анастомозованих органів травлення.

У вітчизняних та закордонних літературних джерелах практично відсутні публікації про роль патології обміну сполучної тканини в розвитку неспроможності швів анастомозів порожнистих органів травлення.

Саме тому метою нашого дослідження було покращення результатів лікування хворих з неспроможністю швів анастомозів порожнистих органів травлення шляхом гістологічного та імуногістохімічного дослідження сполучної тканини в групах пацієнтів із неспроможністю швів та фенотипічними ознаками дисплазії.

\section{1. Матеріал та методи досліджень}

Об'єктом проспективного дослідження були 65 хворих, які лікувались у ДУ «НІХТ імені О.О. Шалімова» впродовж 20172020 pp., 3 яких 21 - 3 неспроможністю швів міжкишкових анастомозів та $44-3$ фенотипічними ознаками недиференційованої дисплазії сполучної тканини (далі - НДСТ). Група контролю - це 40 практично здорових людей, які зіставні за віком і статтю 3 досліджуваними.

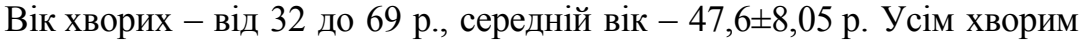
виконували комплексне обстеження, що включало загальноклінічні, спеціальні лабораторні та інструментальні методи дослідження. Для оцінки стану метаболізму сполучної тканини вивчали вміст у сироватці крові вільного оксипроліну та рівень глікозаміногліканів у сечі. НДСТ діагностували за напрацьованою методикою (патент України на корисну модель № 120158 UA) ${ }^{6}$.

${ }^{5}$ Lloyd D., Gabe S., Windsor A. Nutrition and management of enterocutaneous fistula. Br J Surg. 2006; 93(9):1045-1055. doi: 10.1002/bjs.5396.

${ }^{6}$ Usenko O.Y., Voitiv Y.Y. Undifferentiated dysplasia of connective tissue in patients with insufficiency of anastomotic sutures of the gut hollow organs. Klinicheskaia khirurgiia. 2019; 86(6):3-7. doi: 10.26779/2522-1396.2019.06.03. 
Фрагменти нормальних тканин товстої та тонкої кишок, тканин килових мішків та тканин із ділянок неспроможності швів, кишкових нориць та апоневрозу були досліджені на кафедрі патологічної та топографічної анатомії НМАПО імені П.Л. Шупика під керівництвом завідувача кафедри, доктора медичних наук, професора О.О. Дядик.

Для проведення комплексного патоморфологічного дослідження отриманий матеріал фіксувався в 10\%-му розчині нейтрального забуференного формаліну $(\mathrm{pH} \mathrm{7,4)}$ протягом 36-48 годин. Після фіксації за стандартною методикою проводили препарати за допомогою гістопроцесора Thermo scientific Excelsior AS, заливали в парафінові блоки, з яких на ротаційному мікротомі НМ 325 (Thermo Shandon, Англія) виготовляли серійні гістологічні зрізи товщиною 3-4 мкм, які потім забарвлювали гематоксиліном та еозином, пікрофуксином за Ван Гізоном, проводилась PAS-реакція ${ }^{7}$.

В усіх досліджуваних групах було проведено імуногістохімічне дослідження (далі - ІГХД) для оцінки особливостей та властивостей сполучної тканини. Отримані зрізи поміщалися на адгезивні скельця Super Frost Plus (Menzel, Німеччина), потім проводили інкубацію 3 первинними антитілами згідно 3 інструкцією фірм-виробників. Використано систему детекції Master Polymer Plus Detection System (Peroxidase), хромоген ДАБ (Master diagnostica (Гранада, Іспанія)).

ІГХД проведено $з$ такими маркерами (Thermo Scientific, США): моноклональні антитіла (МАТ) до $\alpha$-SMA (1A4(asm-1)) - імуногістохімічний маркер цитоплазматичного актину клітин гладком'язевого диференціювання ${ }^{8}$ моноклональніми антитілами (MAT) до Collagen IV (clone CIV22).

Оцінка експресії маркерів проводилась згідно 3 наявністю характерного коричневого забарвлення клітин різного ступеня інтенсивності відповідно до візуально-аналогової шкали. Інтенсивність експресії оцінювали від 0 - «відсутня» до +++ - «виражена» ${ }^{9}$.

Мікроскопічне дослідження, фотоархивування здійснювали за допомогою світлооптичних мікроскопів Zeiss (Німеччина) «Axio

${ }^{7}$ Rosai and Ackerman's Surgical Pathology Seven edition / edited by J. RosaiElsevier Inc, 2011.Vol 1, Ch. 2,3-p. 25-95.

${ }^{8}$ Shinde A.V., Humeres C., Frangogiannis N.G. The role of alpha-smooth muscle actin in fibroblast-mediated matrix contraction and remodeling. Biochim Biophys Acta. 2016; 1863:298-309.

${ }^{9}$ Dabbs D. / Diagnostic Immunohistochemistry, $4{ }^{\text {th }}$ Edition Theranostic and genomic applications. 2014. 960 p. 
Imager A2» із системою обробки даних та камерою Axiolam ERc 5s за збільшення об'єктивів 5×, 10×, 20×, 40×, бінокулярної насадки 1,5 та окулярів P1 10×/23 та «Primo Star» (Німеччина) із системою обробки даних та камерою Aхіосаm 105 color за збільшення об'єктивів 4×, 10×, $40 \times$, бінокулярної насадки 1,5 та окулярів WF 10×/18.

Статистична обробка результатів досліджень проводилась із використанням електронних таблиць Microsoft ${ }^{\circledR}$ Office Excel (2017) та програми для статистичної обробки Statgraphics Professional 16.0.03. Для перевірки гіпотези про рівність середніх використовували критерій Ст'юдента для нормально розподілених вибірок i критерій Уілкоксона-Манна-Уїтні для вибірок, розподіл яких відрізнявся від нормального. Перевірку закону розподілу виборок на нормальність проводили за допомогою критерію Шапіро-Вілкі. Статистичну залежність між величинами перевіряли за допомогою кореляційного аналізу за Спірменом.

\section{2. Гістологічний та імуногістохімічний аналіз сполучної тканини в групі контролю}

У даній групі було досліджено 40 зразків нормальних тканин товстої та тонкої кишок.

Стінка тонкої кишки має слизову оболонку, підслизову основу, м'язову і серозну оболонки. Відзначається наявність ворсинок на внутрішній поверхні. $Є$ трубчасті поглиблення у власній пластинці слизової оболонки - крипти. Під криптами розташована основна частина м'язової пластинки. Підслизова основа утворена пухкою волокнистою сполучною тканиною, в якій відзначаються нервові ганглії і численні судини. У шарах стінки тонкої кишки відзначаються дуоденальні залози і лімфатичні фолікули (рис. 1).

Стінка товстої кишки містить слизову оболонку, підслизову основу, м'язову і серозну оболонки. На відміну від слизової оболонки тонкої кишки, слизова оболонка товстої кишки не утворює ворсинок, але має крипти - трубчасті поглиблення. У порівнянні 3 тонкою кишкою ці крипти глибше i ширше. Власна пластинка утворює тонкі сполучнотканинні прошарки між криптами. Під криптами розташована м'язова пластинка, яка складається 3 двох шарів. У підслизовій основі, крім пухкої волокнистої сполучної тканини, відзначаються судини і нервові сплетення, жирові клітини, поодинокі лімфоїдні вузлики (рис. 2). 


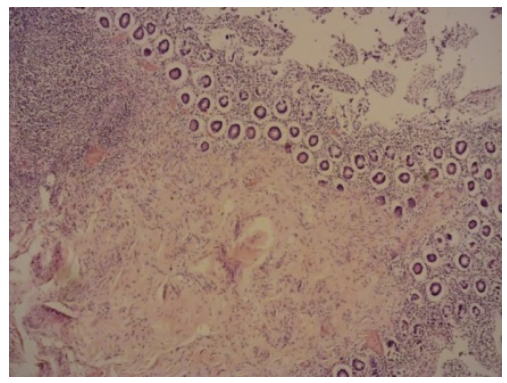

Рис. 1. Фрагмент тканини тонкої кишки звичайної гістологічної будови. Забарвлення гематоксилін-еозином. Збільшення х50

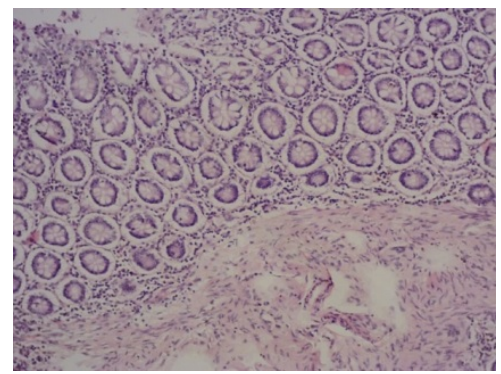

Рис. 2. Фрагмент тканини товстої кишки звичайної гістологічної будови. Забарвлення гематоксилін-еозином. Збільшення х100

Під час гістохімічного дослідження з використанням PAS-реакції доведено функціональну спроможність у різних відділах кишки нормальної будови, у вигляді збереження секреції слизу та нормального розповсюдження келихоподібних клітин (рис. 3,4 ).

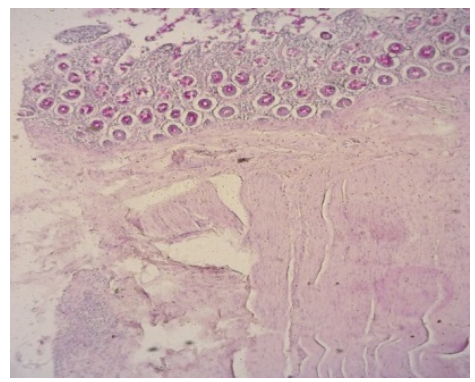

Рис. 3. Фрагмент тканини тонкої кишки звичайної гістологічної будови зі збереженням секреції слизу. PAS-реакція. Збільшення х50 


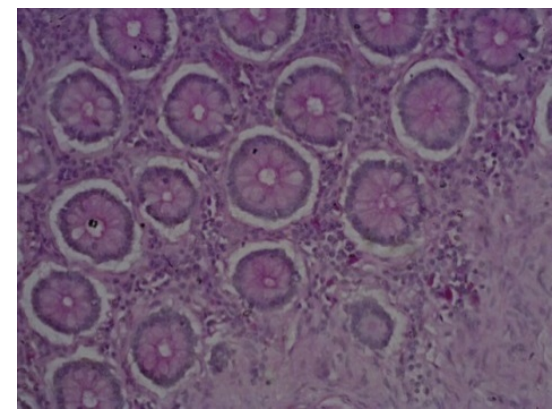

Рис. 4. Фрагмент тканини товстої кишки звичайної гістологічної будови зі збереженням секреції слизу. Забарвлення PAS-реакція. Збільшення х200

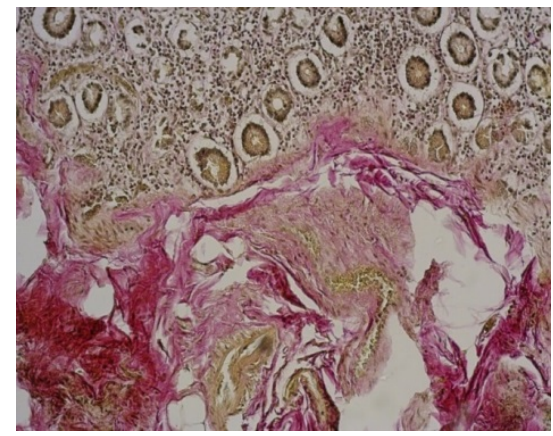

Рис. 5. Фрагмент тканини тонкої кишки звичайної гістологічної будови. Забарвлення за Ван Гізоном. Збільшення х100

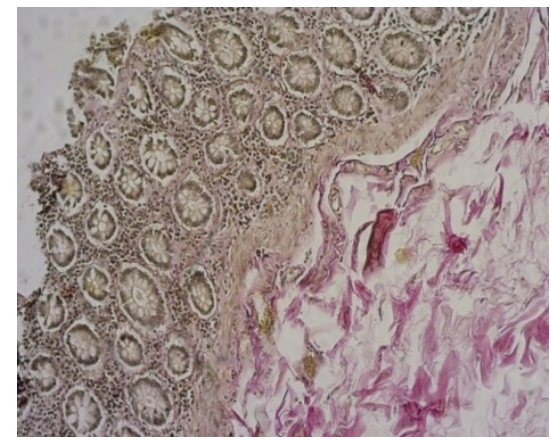

Рис. 6. Фрагмент тканини товстої кишки звичайної гістологічної будови. Забарвлення за Ван Гізоном. Збільшення х100 
Оцінка ступеня зрілості фіброзної тканини була здійснена за допомогою забарвлення за Ван Гізоном, що зафарбовує волокна сполучної тканини різного ступеня зрілості в червоний колір (різного ступеня інтенсивності), гладком'язові волокна набувають жовтого та/або жовто-цегляного кольору (рис. 5, 6).

Для оцінки ступеня спроможності гладком'язового компоненту використано ІГХД з МАТ до $\alpha$-SMA, який є маркером цитоплазматичного актину клітин гладком'язового диференціювання. Дана ізоформа актину $\epsilon$ позитивною в міофібробластах, а також $\epsilon$ маркером переходу від епітелію до мезенхіми. $\alpha$-SMA відіграє важливу роль у фіброгенезі та може виявлятися в клітинах гладких м'язів, міофібробластах і кровоносних судинах ${ }^{10}$. Експресія та наявність позитивних $\alpha$-SMA-клітин корелює з активацією фібрілогенезу, відображає фенотипову наявність міофібробластів. Фенотип міофібробластів у експресії $\alpha$-SMA та продукуванні сполучення позаклітинного матриксу регулюється $\beta$-трансформуючим фактором роста (TGF- $\beta)^{11}$. Скоротливі властивості міофібробластів пов'язані з експресією $\alpha$-SMA та беруть участь у запалені, загоєнні, фіброзі та канцерогенезі ${ }^{12}$.

Під час проведення ІГХД з МАТ до $\alpha$-SMA встановлено виражену позитивну реакцію в гладком'язових волокнах 3 інтенсивністю забарвлення від ++ до +++, як у ділянках тканини з незначним фіброзним компонентом тонкої кишки (рис. 7), так і в зонах із більшим розповсюдженням сполучної тканини товстої кишки (рис. 8).

Для візуалізації сполучнотканих компонентів, у тому числі в базальних мембранах різних структур, застосовувалось ІГХД з МАТ до Collagen IV.

${ }^{10}$ Cherng S., Young J., Ma H. Alpha-smooth muscle actin ( $\alpha$-SMA) J Am Sci. 2008; 4:10; Shinde A.V., Humeres C., Frangogiannis N.G. The role of alpha-smooth muscle actin in fibroblast-mediated matrix contraction and remodeling. Biochim Biophys Acta. 2016; 1863:298-309.

${ }^{11}$ Grotendorst G.R., Rahmanie H., Duncan M.R. Combinatorial signaling pathways determine fibroblast proliferation and myofibroblast differentiation. FASEB J. 2004;18:469-79; Sun K.H., Chang Y., Reed N.I. et al. alpha-Smooth muscle actin is an inconsistent marker of fibroblasts responsible for force-dependent TGFbeta activation or collagen production across multiple models of organ fibrosis. Am J Physiol Lung Cell Mol Physiol. 2016; 310:824-36.

${ }^{12}$ Rao K.B., Malathi N., Narashiman S. et al. Evaluation of myofibroblasts by expression of alpha smooth muscle actin: a marker in fibrosis, dysplasia and carcinoma. $\mathrm{J}$ Clin Diagn Res. 2014; 8:ZC14-7. 


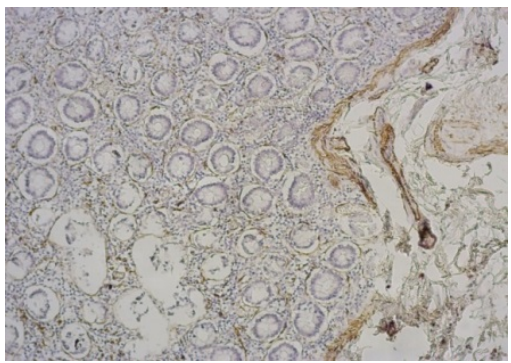

Рис. 7. Позитивна експресія в м'язових волокнах тканини тонкої кишки в зоні розростання сполучної тканини. ІГХД з МАТ до $\alpha$-SMA. Збільшення х100

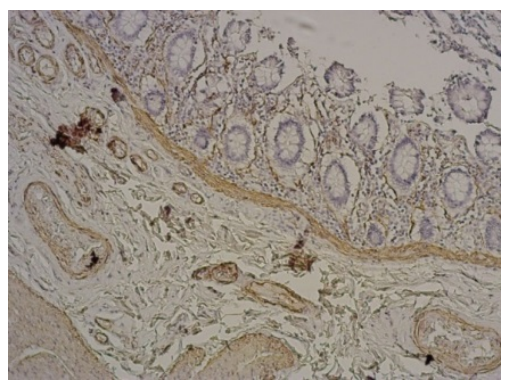

Рис. 8. Позитивна експресія в м'язових волокнах тканини товстої кишки в зоні розростання сполучної тканини.

ІГХД з МАТ до $\alpha$-SМА. Збільшення х100

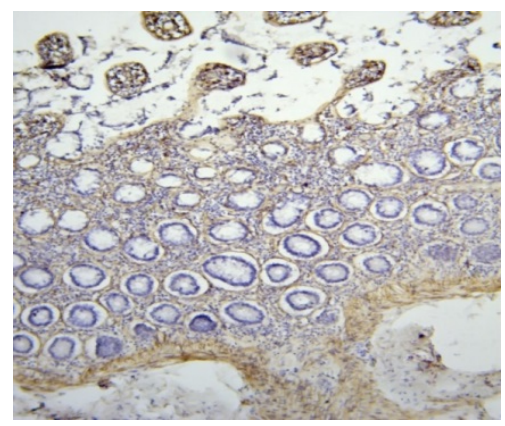

Рис. 9. Помірна позитивна експресія в гладком'язових волокнах з інтенсивністю забарвлення до ++ в зоні розростання сполучної станини у фрагментах тканини тонкої кишки. ІГХД з МАТ до Collagen IV. Збільшення х100 
Під час проведення IГХД з MAT до Collagen IV виявлено помірну позитивну реакцію в гладком'язових волокнах 3 інтенсивністю забарвлення до ++ у ділянках власної пластинки, які представлені у фрагментах тканини як тонкої (рис. 9), так і товстої кишки (рис. 10).

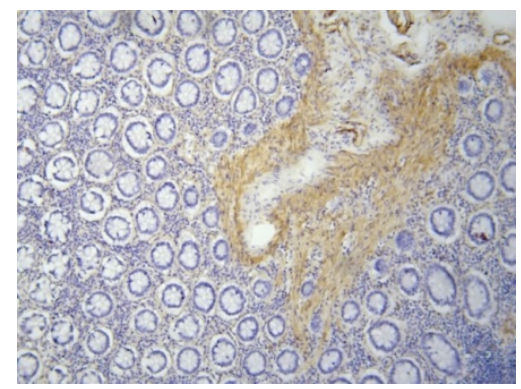

Рис. 10. Помірна позитивна експресія в гладком'язових волокнах $з$ інтенсивністю забарвлення до ++ в зоні розростання сполучної станини у фрагментах тканини товстої кишки.

ІГХД з МАТ до Collagen IV. Збільшення х50

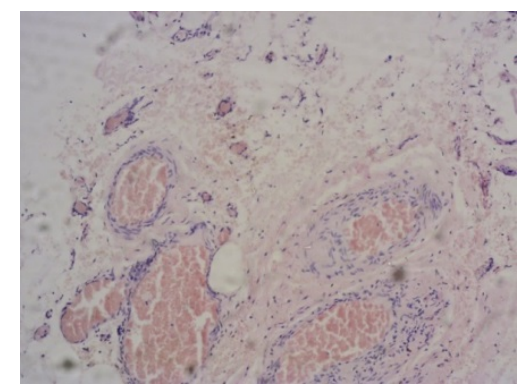

Рис. 11. Тканина килового мішку з ознаками лімфоплазмоцитарної інфільтрації, розростанням сполучної тканини, ангіоматозом, повнокрів'ям судин. Забарвлення гематоксилін-еозином. Збільшення х100

3. Гістологічний та імуногістохімічний аналіз сполучної тканини в групі паціснтів із фенотипічними ознаками НДСТ

У даній групі було досліджено 44 зразки тканин апоневрозу та грижових мішків.

У тканині килового мішку відмічається незначна, в тому числі й периваскулярна лімфоплазмоцитарна інфільтрація, розростання 
сполучної тканини, ангіоматоз, повнокрів'я судин та гіаліноз їхніх стінок (рис. 11).

Для візуалізації фіброзної тканини, оцінки ступеня іiі зрілості було проведено гістохімічне забарвлення за Ван Гізоном. Волокна сполучної тканини різного ступеня зрілості забарвлені в червоний колір із різним ступенем інтенсивності, гладком'язові волокна набувають жовтого кольору. Зустрічались ділянки сполучної тканини 3 наявністю судин мікроциркуляторного типу та вогнищами фіброзної тканини, яка представлена «ніжними» пучками волокон червоного кольору (рис. 12).

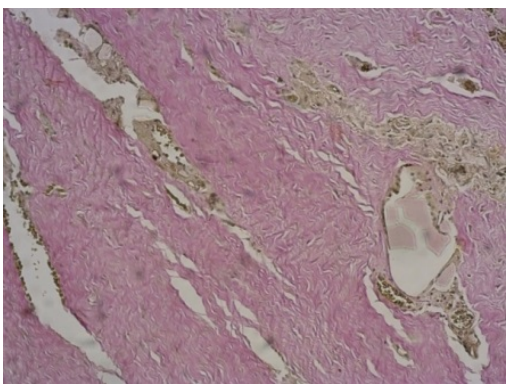

Рис. 12. Фрагмент тканини килового мішку з групами волокон фіброзної тканини. Забарвлення за Ван Гізоном. Збільшення х100

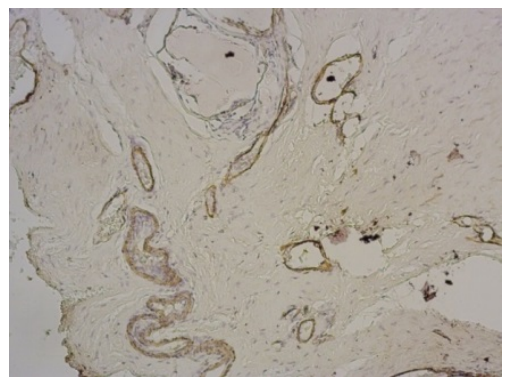

Рис. 13. Тканина килового мішка зі слабо вираженою інтенсивністю експресії до 1 балу на окремих ділянках сполучної тканини, в стінках судин. ІГХД з МАТ до $\alpha$-SMA. Збільшення х100 
Під час проведення ІГХД з МАТ до $\alpha$-SMA в зоні фіброзної тканини відмічалась вогнищева експресія з інтенсивністю до 1 балу (рис. 13), яка переважно представлена в стінках судин (рис. 14).

Під час проведення IГХД з МАT до Collagen IV тканини килового мішка виявлено слабопозитивну реакцію переважно в базальній мембрані судин, у гладком'язових клітинах м'язового шару стінки судин $з$ інтенсивністю забарвлення до + , вогнищево в ділянках сполучної тканини (рис. 15).

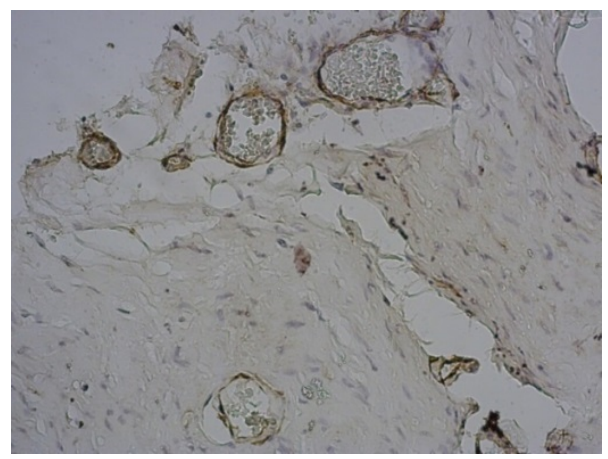

Рис. 14. Тканина килового мішка з вогнищевою експресією в стінках судин інтенсивністю до 1 балу. ІГХД з МАТ до $\alpha$-SМА. Збільшення х200

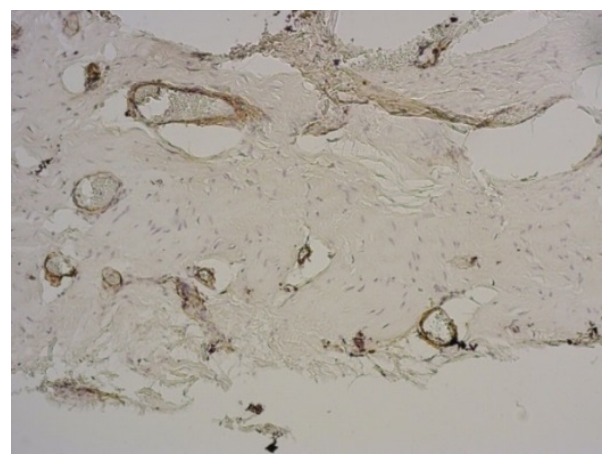

Рис. 15. Слабка експресія в базальній мембрані, в гладком'язових клітинах м'язового шару стінки судин у фрагментах тканини килового мішка. IГХД з МАT до Collagen IV. Збільшення х100 


\section{4. Гістологічний та імуногістохімічний аналіз сполучної}

тканини в групі паціснтів із неспроможністю швів порожнистих органів травлення

У досліджуваній групі пацієнтів 3 неспроможністю анастомозів порожнистих органів травлення, що лікувались у клініці, переважну більшість $(66,7 \%)$ становили хворі, оперовані в інших лікувальних закладах України, котрі поступили у HIXT з метою визначення тактики та проведення подальшого лікування. У клініку НIXТ пацієнти госпіталізовувалися 3 такими діагнозами: тонко-, товстокишкові нориці (8), ілео-, колостоми (7), абсцеси, інфільтрати черевної порожнини (5), заочеревинна флегмона (2).

$\mathrm{У}$ тканинах із ділянок неспроможності швів (рис. 16, 17) відмічались такі гістологічні зміни: нерівномірно виражене розростання сполучної тканини, дифузна та/або вогнищева лімфогістіоплазмоцитарна інфільтрація, зони ангіоматозу, повнокрів'я судин та гіаліноз їхніх стінок.

У разі забарвлення за Ван Гізоном візуалізуються пучки фіброзної тканини (червоного кольору), що дифузно проростають між м'язовими волокнами (рис. 18), на окремих ділянках фіброзна тканина виповнює більшість площі поля зору (рис. 19).

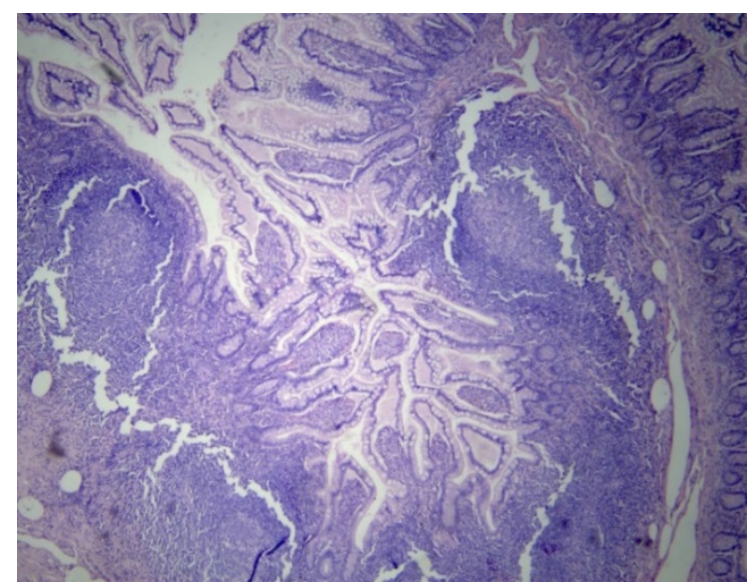

Рис. 16. Тканина 3 ділянки неспроможності швів $з$ ознаками вираженої лімфогістіоплазмоцитарної інфільтрації, розростанням сполучної тканини, ангіоматозом, повнокрів'ям судин. Забарвлення гематоксилін-еозином. Збільшення $\mathbf{4 0}$ 


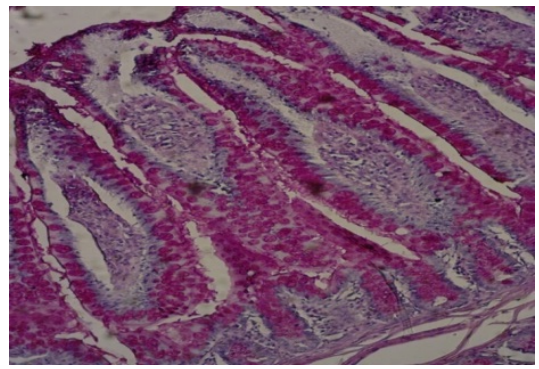

Рис. 17. Тканина $з$ ділянки неспроможності швів, збереження секреції слизу. Забарвлення PAS. Збільшення х100

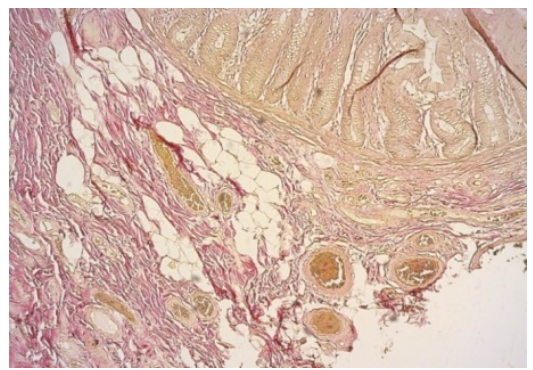

Рис. 18. Фрагмент тканини з ділянки неспроможності швів, нерівномірно виражене розростання сполучної тканини різного ступеня зрілості. Забарвлення за Ван Гізоном. Збільшення х50

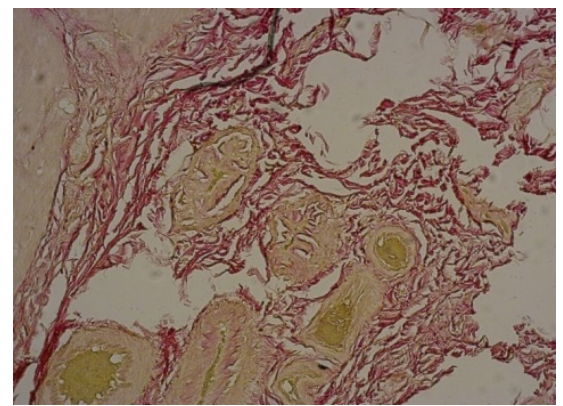

Рис. 19. Фрагмент тканини кишкової нориці з пучками фіброзної тканини, що дифузно проростають між м'язовими волокнами, периваскулярно. Забарвлення за Ван Гізоном. Збільшення х100 
Під час проведення ІГХД з МАТ до $\alpha$-SMA відмічалась незначна, переважно вогнищева експресія в стінках судин, у зоні власної пластинки, ділянках склерозу з інтенсивністю переважно до 1 балу в ділянках тканини 3 неспроможністю швів (рис. 20). У ділянках 3 апоневрозом у стінках судин, у фіброзній тканині інтенсивність експресії $\alpha$-SMA була від 1 до 2 балів.

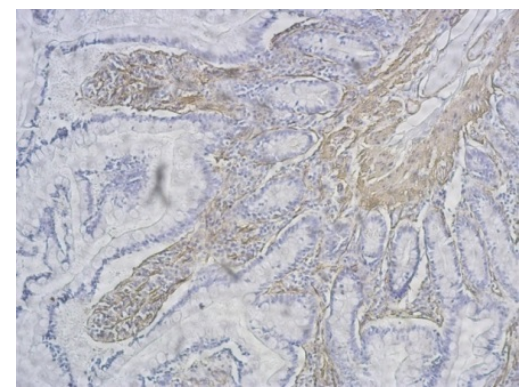

Рис. 20. Тканина з неспроможністю швів з вогнищевою експресією з інтенсивністю до 1 балу. ІГХД з МАТ до $\alpha$-SMA. Збільшення х100

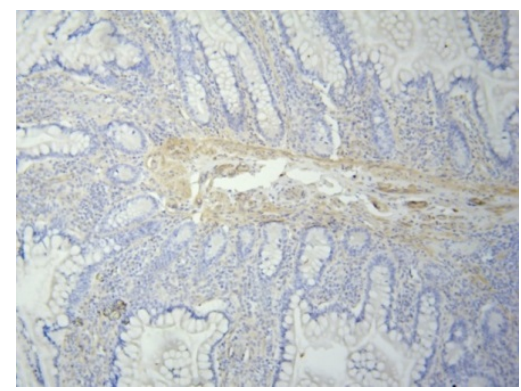

Рис. 21. Переважно слабка позитивна експресія

у власній пластинці, в зоні розростання сполучної станини до + у фрагментах тканини з ділянками неспроможності швів.

ІГХД з МАТ до Collagen IV. Збільшення х100

Під час проведення IГХД з МАТ до Collagen IV тканин у ділянках неспроможності швів (Рис. 21) відмічається переважно слабовиражена позитивна експресія в базальній мембрані судин, у гладком'язових клітинах м'язового шару стінки судин, у ділянках сполучної тканини з інтенсивністю забарвлення до +, вогнищево до ++. 


\section{ВИСНОВКИ}

У досліджуваних групах пацієнтів 3 фенотипічними ознаками недиференційованої дисплазії сполучної тканини та 3 неспроможністю анастомозів відмічаються схожі гістологічні зміни:

- виражене розростання сполучної тканини, дифузна або вогнищева лімфогістіоплазмоцитарна інфільтрація, ангіоматоз, повнокрів'я судин, гіаліноз їхніх стінок;

- візуалізуються пучки фіброзної тканини, що дифузно проростають між м'язовими волокнами, на окремих ділянках фіброзна тканина виповнює більшість площі поля зору;

- під час ІГХД з МАТ до $\alpha$-SMA нерівномірна, вогнищева експресія в клітинах гладком'язового диференціювання та фібробластах;

- під час IГХД з MAT до Collagen IV тканин відмічається нерівномірна слабка та/або помірна позитивна експресія в базальній мембрані судин, у гладком'язових клітинах м'язового шару стінки судин, у ділянках сполучної тканини.

Схожі гістологічні, гістохімічні, імуногістохімічні ознаки в групах 3 фенотипічними ознаками недиференційованої дисплазії сполучної тканини та 3 неспроможністю швів міжкишкових анастомозів підтверджують роль патології сполучної тканини в розвитку післяопераційних ускладнень, а саме зовнішніх кишкових нориць.

Наявність дисплазії сполучної тканини у хворих 3 неспроможністю швів анастомозів порожнистих органів травлення $\epsilon$ обтяжуючим коморбідним фактором, що необхідно враховувати у виборі адекватної хірургічної тактики і комплексного патогенетично обгрунтованого лікування.

\section{АНОТАЦІЯ}

Обстежено 65 хворих, які лікувались у ДУ «НІХТ імені О.О. Шалімова» впродовж 2017-2020 pp., 3 яких 21 - із неспроможністю швів міжкишкових анастомозів та 44 - 3 фенотипічними ознаками дисплазії сполучної тканини.

Під час комплексного гістологічного та імуногістохімічного дослідження фрагментів тканин тонкої та товстої кишок, аноневрозу, грижових мішків виявлено схожі морфологічні зміни у групах $з$ фенотипічними ознаками недиференційованої дисплазії сполучної тканини та 3 неспроможністю швів міжкишкових анастомозів. Під час імуногістохімічного дослідження тканин із моноклональними антитілами до $\alpha$-SMA в обох групах виявлено 
нерівномірну, вогнищеву експресію в клітинах гладком'язового диференціювання та у фібробластах; 3 моноклональними антитілами до Collagen IV відмічається помірна позитивна експресія в базальній мембрані судин, у гладком'язових клітинах м'язового шару стінки судин, у ділянках сполучної тканини, що є ознаками патологічного ремоделювання сполучної тканини.

\section{ЛІТЕРАТУРА}

1. Неспроможність кишкових анастомозів. Харківська хірургічна школа / В.В. Бойко та ін. 2013. № 6 (23). С. 5-8.

2. Pitel S., Lefèvre J.H., Tiret E. Redo coloanal anastomosis: a retrospective study of 66 patients. Ann Surg. 2012. 256 (5). 806-811.

3. Sharonne de Z., Usama A.A., Rogier A.R. Update of complications and functional outcome of the ileo-pouch anal anastomosis: overview of evidence and meta-analysis of 96 observational studies. Int. J. Colorectal Dis. 2012. 27. 843-853.

4. Enterocutaneous fistula complicating trauma laparotomy: A major resource burden. Am Surg / P.G.R. Teixeira et al. 2009.75 (1). 30-32.

5. Lloyd D., Gabe S., Windsor A. Nutrition and management of enterocutaneous fistula. Br J Surg. 2006. 93 (9). 1045-1055. doi: $10.1002 /$ bjs.5396

6. Usenko O.Y., Voitiv Y.Y. Undifferentiated dysplasia of connective tissue in patients with insufficiency of anastomotic sutures of the gut hollow organs. Klinicheskaia khirurgiia. 2019. 86 (6). 3-7. doi: 10.26779/2522-1396.2019.06.03

7. Rosai and Ackerman's Surgical Pathology Seven edition / edited by J. Rosai. Elsevier Inc, 2011. Vol 1. Ch. 2, 3. P. 25-95.

8. Shinde A.V., Humeres C., Frangogiannis N.G. The role of alphasmooth muscle actin in fibroblast-mediated matrix contraction and remodeling. Biochim Biophys Acta. 2016. 1863. 298-309.

9. Dabbs D. Diagnostic Immunohistochemistry, 4th Edition. Theranostic and genomic applications. 2014. 960 p.

10. Cherng S., Young J., Ma H. Alpha-smooth muscle actin ( $\alpha$-SMA) J Am Sci. 2008. 4. 10 ; Shinde A.V., Humeres C., Frangogiannis N.G. The role of alpha-smooth muscle actin in fibroblast-mediated matrix contraction and remodeling. Biochim Biophys Acta. 2016. 1863. 298-309.

11. Grotendorst G.R., Rahmanie H., Duncan M.R. Combinatorial signaling pathways determine fibroblast proliferation and myofibroblast differentiation. FASEB J. 2004. 18. 469-79; alpha-Smooth muscle actin 
is an inconsistent marker of fibroblasts responsible for force-dependent TGFbeta activation or collagen production across multiple models of organ fibrosis. Am J Physiol Lung Cell Mol Physiol / K.H. Sun et al. 2016. 310. 824-36.

12. Evaluation of myofibroblasts by expression of alpha smooth muscle actin: a marker in fibrosis, dysplasia and carcinoma. J Clin Diagn Res. / K.B. Rao et al. 2014. 8. 14-7.

\section{Information about the author:} Voitiv Ya. Yu., $\mathrm{MD}, \mathrm{PhD}$ (Med), Associate Professor, Associate Professor at the Department of Surgery and Transplantology Shupyk National Medical Academy of Postgraduate Education 30, Heroyv Sevastopolya str., Kyiv, 03680, Ukraine 